\title{
Bifurcated Belgium shows the strain from collaboration between cultures
}

Brussels. As the European Communities (EC) move towards a unified Europe, it is ironic that Belgium, in whose capital their headquarters is housed, is consolidating its own division into separate regions. But the path to federalization has not been smooth, and Belgian science now suffers

the consequences of a loss of cooperation across the cultural divide.

Like many of the countries in Europe now splitting into ethnically defined fragments, Belgium is a product of recent history. Flemishspeaking Flanders in the north and Frenchspeaking Wallonia in the south were thrown together in the 1830 s to be a buffer between France and Germany. But the artificial boundaries caused economic and cultural tensions, and in 1988 a federal system was created.

Three semi-autonomous regions Wallonia, Flanders and bilingual Brussels were founded, with Flemish speakers outnumbering French speakers by 55 per cent to 38 per cent. Responsibility for a large part of the nation's science policy has shifted quickly from the national government to the regions and cultural communities.

Belgian research is planned within three broad areas. The national government directly funds some programmes, such as the BFr500 million (US\$17 million) AIDS programme, that are in the national interest. This year, about BFr12 billion has been set aside for this purpose. The regions control economic policies and handle applied science and technology while the communities, which are responsible for all cultural issues, deal with basic research.

Flanders and Wallonia operate as two countries. Budgets are divided roughly 55:45 according to a complex formula involving population, fiscal revenue and extent of territory. This also applies to the National Fund for Science Research (NFSR), whose two administrations are strictly separate. A French speaker cannot apply for a grant from the Flemish NFSR, nor can a Flemish scientist ask for French funding.

But the two parts do share the 40 -odd, discipline-orientated 'science committees' that assess grant proposals. These committees are usually composed of five Flemish-speaking and five Frenchspeaking scientists plus two foreigners who must be able to speak at least one of the federalization has undermined established systems for choosing the best science. Review panels tend to fragment into their ethnic groups, and members show little interest in commenting on grant proposals from the opposite community. The result is half the desired input into the process.

At the most recent meeting of the physiology and pathophysiology committee, for example, the French reviewers were totally absent from discussions about Flemish proposals, and vice versa.

Federalization has also changed the way in which national funds are distributed. Scientists complain that decisions are now made by politicians. The new Flemish government has promised to reduce the influence of the national government, but so far this has not happened.

Scientists are also unhappy that a larger share of the research budget is going directly to universities in the two communities on the basis of their
nrolments rather than the quality of their research. Since 1987, the amount of research money given to universities in Flanders for their own allocation has risen by more than a third to

languages. According to Jos Traest, general BFr379 million. secretary of the Flemish side, this mix should allow decisions to be made independently of financial interests.

Why then is the system not working? There are two main problems. First, the lines of authority between the three levels of government are unclear, making it hard to reach decisions. In addition, large-scale collaborations between French and Flemish speakers have become difficult to arrange. Marcus Bogaert of the J.F. \& C. Heymans Institute in Ghent once had a regular collaboration on ageing and disease states with a French-speaking group at the Catholic University of Louvain, but decided this year that the process had become 'so cumbersome that it was not worth the bother'. French-speaker Arsène Burny, a molecular biologist at the University of Brussels, says that it is easier to 'forget your neighbour 30 $\mathrm{km}$ up the road' and arrange an international collaboration; the process is no more complicated and the result carries more prestige.

Second, scientists feel that the process of
Walter Fiers, a molecular biologist at the University of Ghent, says that most universities, to keep their departments happy, tend to allocate the money evenly, and do not use a standard scientific peer-review system. "Science is so important and so expensive that its funding should be selective, not democratic", he says.

But Claude Truffin of Belgium's National Ministry of Science says that many of the problems are just a consequence of settling in. Although admitting that the regions and communities are not cooperating well and that the national government is failing to coordinate activities, Truffin says that "we may not have set up a very efficient and well-harmonized system, but there is nothing stopping us from moving in that direction".

Despite complaints about the system, there are few calls for radical change. As a consequence, it seems likely that the process of "settling in" may take a few more years.

Alison Abbott 